\title{
INFECTION CAPACITY OF THE PATHOGENS Penicillium italicum AND P. expansum IN ORANGE DURING STORAGE
}

\author{
Sonja P. Veljović ${ }^{*}$, Krissana Boonsiri ${ }^{2}$, Michael K. Maina ${ }^{3}$, Emmanuel M. Semavor ${ }^{4}$, Surajit Mitra ${ }^{5}$ \\ ${ }^{1}$ Economics Institute, Kralja Milana 16, 11000 Belgrade, Serbia \\ ${ }^{2}$ Nakhonsawan Colledge of Agriculture and Technology, Thailand \\ ${ }^{3}$ Kenya Horticultural Exporters, Kenya \\ ${ }^{4}$ Volta Integrated Agricultural Development Ltd., Ghana \\ ${ }^{5}$ Bidhan Chandra Krishi Viswavidyalaya Agricultural University, Department of Post-Harvest \\ Technology, Mohanpur-741252, Nadia, West Bengal, India
}

\author{
*Corresponding author: \\ Phone: +38113613417 \\ Fax: +38113613037 \\ E-mail address: pecic84@hotmail.com; sonja.veljovic@ecinst.org.rs
}

ABSTRACT: Penicillium italicum and $P$. expansum are important pathogens causing decay in most fruits and vegetables. In this study, orange fruits were inoculated with these two species of fungus and stored 14 days with or without bagging, in a cold room for 11 days and 3 days at room temperature to determine the effect of bagging and infection capacities of both molds on oranges during storage. The results indicated that $P$. expansum can grow on orange peel with smaller colony diameter than $P$. italicum in bagged and unbagged fruits. Total soluble solids (TSS) and firmness were not affected by bag. Gas composition of the bags showed low oxygen and high carbon dioxide concentration after fourteen days of storage. Bagged fruits decreased decay caused by $P$. italicum and weight loss, and delayed changes in firmness, TSS and acidity compared with control fruits. The study suggests that bagging may be a promising option for controlling decay, maintaining fruit quality and extending shelf-life of oranges.

Key words: orange, inoculation, bagging, infection capacity, fruit quality

\section{INTRODUCTION}

Sweet orange (Citrus sinensis) is one of the most important citrus fruit. It is widely grown non climacteric fruit with a pleasant aroma and abundant in a wide variety of phytonutrient compounds. Health benefits of eating oranges are the main reason for annually increasing demand for orange and its products worldwide. The total world production of orange in 2013 was estimated at 71.6 million metric tons (FAOstat, 2016), and most of producers are from American and African countries. After harvesting the quality of orange cannot be improved, but with adequate storage conditions it can be preserved for a longer period.

In order to reduce the unwanted losses caused by pathogens, it is important to understand the mechanism of infection. The severity of epidemics is governed by the main and interacting effects of three components of the disease syndrome, which are the host, the pathogen and the environment. Host variables include the type and degree of cultivar resistance; pathogen variables include the race, its virulence and infectivity, and the amount of initial inoculums; environmental variables include solar intensity, photoperiod and temperature (Ben-Yephet and Shtien- 
berg, 1997). The possibility of plant-pathogen specificity is that plants have an innate ability to recognize potential of invading pathogens and to mount successsful defenses. In a converse manner, successful pathogens cause infection disease because they are able to evade recognition or suppress host defense mechanism or both (Staskawicz, 2001). Basal resistance begins with the recognition of elicitors which are derived from the microorganism. After that ions fluxes, phosphorylation/ dephosphorylation of proteins, and the production of signaling molecules such as salicylic acid, jasmonic acid, ethylene, and reactive oxygen species are activated. This leads to the regulation of gene expression and the induction of defense responses. Some microorganisms become virulent by the production of effector molecules which contribute to their virulence, for example, by the suppression of plant defense. In these compatible interactions the virulent pathogen can spread in the susceptible plant (Berger et al., 2007).

According to previous research, Penicillium digitatum and $P$. italicum are responsible for $80 \%$ of total postharvest citrus fruit decay under Mediterranean climate condition (Embaby et al., 2013). The major postharvest decays of citrus caused by $P$. digitatum occurred in arid and subtropical climate (Adaskaveg and Forster, 2015). Also, important postharvest pathogen is $P$. expansum the cause of blue mold (Rosenberger, 1990). Vilanova et al. (2012 a) found that a non-host pathogen, $P$. expansum, can infect citrus fruit in the mature stage. The fungus, $P$. expansum, not only causes fruit decay but also produces the carcinogenic mycotoxin patulin. This toxin may rise to unacceptable levels in fruit destined for processing and may also result in off flavors. The symptoms start with soft watery brown spots, which enlarge rapidly at $20-25^{\circ} \mathrm{C}$, blue-green spores are formed on the lesion surface in humid conditions. During storage, infection can occur even at $0^{\circ} \mathrm{C}$, but decay proceeds slowly and usually develop rapidly only when fruits are returned to warm temperatures (Barkai-Golan and Paster, 2008).
$P$. italicum (blue mould) causes a destructive fruit rot of citrus. The earliest symptoms are a soft water-soaked area on the peel, followed by development of a circular colony of white mould. Bluish asexual spores form at the center of the lesion, the white margin is generally not more than about $2 \mathrm{~mm}$ wide. A halo of water soaked, faded tissue surrounds the lesion. The fruit rapidly spoils and collapses, with sporulation sometimes occurring internally. Spores of fungi are invariably present in the atmosphere of citrus growing areas and initial infection of fruit is characteristical via wounds in the peel. Fruit piercing insects such as the Mediterranean fruit fly can cause injuries whilst the fruits are still on tree, permitting pre-harvest infection which may be undetectable at the time of picking. Infection also occurs via wounds sustained during harvesting and handling, the fruit being especially susceptible during periods of wet weather (Snowdon, 1990).

Citrus peel contains many bioactive compounds that stimulates the growth of $P$. digitatum and $P$. italicum in a greater degree than $P$. expansum (Stange et al., 2002). Four main volatiles in the peel of various citrus fruit cultivars are limonene, myrcene, $\alpha$-pinene and $\beta$-pinene. The most germ tube elongation of $P$. italicum stimulated by myrcene and then followed by limonene. Four main volatiles inhibited or had no effect on $P$. expansum (Droby et al., 2008). Wound response is an important factor in the resistance of oranges to $P$. digitatum and $P$. expansum. Lignin formation seems to be involved in orange wound response (Vilanova et al., 2013).

The growths of pathogen on fruit need the suitable environment and specific host. The cold temperature in storage cannot repress the widespread of blue mold disease in fruit if the fruit has the mechanical damages (Filtenborg et al., 1996). Adaskaveg and Foster (2015) found these fungi at storage temperature below $10^{\circ} \mathrm{C}$. The infections of the pathogen take place through the wounds where the nutrients are available to stimulate the spore germination and it can spread in the pack cartons more rapidly in cold storage. 
The aim of this research was to investigate the infection capacity of $P$. italicum and $P$. expansum in orange stored with and without bag.

\section{MATERIALS AND METHODS}

\section{Plant materials}

Mature, fresh fruits of sweet orange type Citrus sinensis, procured directly from orchards in southern Israel by the Department of Postharvest Science, Volcani Center were taken as experimental materials. Fruits of uniform size and appearance were subjected to different treatments at random. The oranges wa-shed with $70 \%$ ethanol were divided into six groups, each group was comprised of fifteen fruits.

\section{Pathogens}

Penicillium italicum and $P$. expansum isolated from infected fruits were cultured separately on potato dextrose agar (Difco) for 10 days at $24{ }^{\circ} \mathrm{C}$. Spores were washed and collected by filtration through eight layers of cheesecloth to remove most of the hyphal fragments, and the concentration of the spore suspension was adjusted to $4 \times 10^{5}$ with a haemocytometer before inoculation. Control fruits were stored in carton containers without any treatment.

\section{Inoculation}

Fruits were inoculated by piercing the skin with a tool incorporating three $0.5-\mathrm{mm}$ diameter needles to a depth of $1.5 \mathrm{~mm}$ at two sites center of the fruit. The tool was immersed in a suspension of $P$. italicum spores prior to the piercing operation. The same procedure was followed for inoculation of orange fruits with $P$. expansum. Each treatment consisted of 3 fruits with five replications. Packaging of orange fruit was done with low density polyethylene (LDPE) immediately after inoculation. Inoculated and control fruits both bagged and un-bagged were kept at $10^{\circ} \mathrm{C}$ for 11 days and at $20{ }^{\circ} \mathrm{C}$ for 3 days. The relative humidity in the storage was $83 \%$.

\section{Physico-chemical analysis}

Each orange fruit was weighed before packaging and opening after 14 days of storage, and the proportional weight loss was calculated. Firmness was determined by measuring the force required for $2 \mathrm{~kg}$ using a Cornell fruit firmness tester. The higher value of firmness indicates that the fruit has slower rate of softening. Total Soluble Solids (TSS) of the orange fruits were determined by a Refractometer (Atago CO, Japan), and expressed in \% Brix. The percentage of concentration of oxygen and carbon dioxide was measured by using a digital aparat Oxybaby (WITTGasetechnik, USA) in the LDPE bags before opening them. Titratable acidity (TA) was determined by titrating $5 \mathrm{ml}$ juice with $0.1 \mathrm{~N}$ sodium hydroxide $(\mathrm{NaOH})$ using phenolphthalein as indicator, and expressed in percent of citric acid using the Automatic titrator (665 Dosimat, Metrohm, Switzerland) (AOAC, 1990). The diameter of colony size and lesion area was measured after 14 days of storage in order to obtain information on the rot dynamics of each pathogen as affected by inoculum concentration.

\section{Statistical analysis}

Measurement of weight loss was repeated 10 times, all other measurements were performed in triplicate. The experimental data were expressed as the mean value \pm standard deviation (SD). The results of weight loss, firmness, total soluble solid, titratable acidity, colony size and lesion area, also the content of $\mathrm{O}_{2}$ and $\mathrm{CO}_{2}$ in bags, were subjected to the analysis of variance (ANOVA). Analysis was conducted in a factorial arrangement where the packaging in the bag and inoculation of different Penicillium species were analyzed factors. Tukey's test was used to determine the difference $(p<0.05)$ between the mean values. Statistical analyses were performed with the statistical program Statistica 12 (StatSoft, USA).

\section{RESULTS}

Weight loss. Results indicate that the weight loss was less in bagged fruits than in the unbagged. The main reason for the packaging of oranges in bags is to reduce respiration and moisture loss. The results of factorial ANOVA showed that both factors (packaging and inoculation by different fungi) and their interaction had very significant effect on the weight loses of orange $(p<0.05)$. Unbagged oranges ino- 
culated with $P$. italicum had a statistically significant weight loss, from 2 to 7 times higher losses compared to the control and bagged oranges inoculated with $P$. italicum (Table 1). Based on these results, it can be concluded that the reason for this was spore infection by $P$. italicum. The weight loss of orange inoculated with $P$. italicum can be reduced by bagging.

Firmness. At the end of 14 days of storage, firmness of the orange fruits statistically significantly decreased in all analyzed samples in comparison with results before storing $(3.8 \pm 0.45 \mathrm{~kg})$. Although, the results of ANOVA showed that there was no significant difference in fruit firmness among all the treatment. Based on the results, $P$. expansum bagged maintained the highest fruit firmness level followed by control bagged, control unbagged, $P$. expansum unbagged, $P$. italicum unbagged and $P$. italicum bagged. Highest firmness was achieved by $P$. expansum bagged followed by control bagged.

Loss of firmness is one the factors that limits the quality and postharvest shelf life of fruits. Abdel Wahab and Rashid (2012) confirmed that $P$. italicum affects the shelf life and causes rotting in orange after 45 days of storage. Based on our results it can be concluded that the period of storage had to be longer that fungi significantly effect on the firmness of oranges.
Decreased decay and weight loss in coated oranges during storage were also reported by Abdel Wahab and Rashid (2012) after 45 days of storage.

Total Soluble Solid (TSS). From our experiment, total soluble solids (TSS \%) decreased since the TSS was $13.48 \%$ before storing. However, it was noticed that the changes in TSS contents were relatively small in all experiments except for $P$. italicum-bagged samples. Naturally, infected fruits attained lower TSS content than inoculated fruits (Abdel Wahab and Rashid, 2012) and in our case, the compatible inoculums $P$. italicum had a lower TSS \% than the control and the incompatible $P$. expansum.

However, in all three experiments, it was noticed that bagging decreased TSS \% as compared to the unbagged samples, but reduction was not statistically significant $(p<0.05)$. TSS $\%$ is a function of total dissolved solids and moisture content of the fruit, thus the increase in the TSS of the unbagged samples may be due to faster maturation process and higher water loss of the fruits (Table 2).

Titration acidity \%. The quantity of organic acids expressed as a citric acid decreased in orange fruits with increasing fruit maintenance periods in cold storage (Abdel Wahab and Rashid, 2012).

Table 1.

Effect of Penicillium italicum and $P$. expansum on the weight loss and firmness of citrus fruit after 14 days of storage

\begin{tabular}{llccc}
\hline & \multicolumn{2}{c}{ Weight loss (\%) } & \multicolumn{2}{c}{ Firmness (kg) } \\
Treatments & Bagged & Unbagged & Bagged & Unbagged \\
\hline Control & $0.40 \pm 0.22^{\mathrm{a}}$ & $1.46 \pm 0.24^{\mathrm{a}}$ & $5.10 \pm 0.55^{\mathrm{a}}$ & $5.40 \pm 1.19^{\mathrm{a}}$ \\
$\boldsymbol{P}$. italicum & $0.63 \pm 0.51^{\mathrm{a}}$ & $2.90 \pm 2.13^{\mathrm{b}}$ & $5.90 \pm 1.14^{\mathrm{a}}$ & $5.60 \pm .1 .43^{\mathrm{a}}$ \\
$\boldsymbol{P}$. expansum & $0.76 \pm 0.97^{\mathrm{a}}$ & $1.51 \pm 0.27^{\mathrm{a}}$ & $5.00 \pm 0.87^{\mathrm{a}}$ & $5.40 \pm 0.35^{\mathrm{a}}$ \\
\hline
\end{tabular}

All results are presented as the mean $\pm S D$. Different letters in a column show a significant difference according to Tukey's test at $p<0.05$

Table 2.

Total soluble solid (\% Brix) and titratabile acidity (\%) of citrus fruit inoculated with Penicillium italicum with a bag (Ib), without bag (lub) and $P$. expansum with bag (Eb), without bag (Eub); control with bag (cb), control without bag (cub), after 14 days of storage

\begin{tabular}{ccccccc}
\hline & $\mathbf{C b}$ & $\mathbf{C u b}$ & $\mathbf{l b}$ & $\mathbf{l u b}$ & $\mathbf{E b}$ & Eub \\
\hline $\begin{array}{c}\text { TSS } \\
(\%)\end{array}$ & $12.52 \pm 1.43^{\mathrm{a}}$ & $12.80 \pm 0.81^{\mathrm{a}}$ & $11.74 \pm 0.79^{\mathrm{a}}$ & $12.48 \pm 0.88^{\mathrm{a}}$ & $12.70 \pm 1.14^{\mathrm{a}}$ & $12.98 \pm 1.59^{\mathrm{a}}$ \\
$\begin{array}{c}\text { TA } \\
(\%)\end{array}$ & $0.62 \pm 0.11^{\mathrm{a}}$ & $0.72 \pm 0.21^{\mathrm{a}}$ & $0.74 \pm 0.06^{\mathrm{a}}$ & $0.81 \pm 0.15^{\mathrm{a}}$ & $0.77 \pm 0.06^{\mathrm{a}}$ & $0.85 \pm 0.13^{\mathrm{a}}$ \\
\hline
\end{tabular}

Different letters in a row show a significant difference according to Tukey's test at $p<0.05$ 
The control bagged oranges has decreased in TA \% compared to the other experiments. According to the results of ANOVA, there was no statistically significant influence of different treatment during 15 days of storing. The results indicate that bagging inhibits TA changes in orange and improves its quality if handled properly (Table 2). Abdel Wahab and Rashid (2012) also reported delayed changes in loss of firmness, TSS and total acidity.

Spore size and lesion area. The results of ANOVA showed that factors and also interaction of two factors (inoculation*bagging) had a very significant influence on the size of colony and decay $(p<0.05)$ (Figure 1). The blue molds attack oranges and spread quickly when the environment is favorable for growth while $P$. expansum does not attack orange except under some extreme condition. The bagging has strengthened the decay in the oranges infected with $P$. expansum, but did not have significant effect on the colony growth. The results from our experiment showed that the growth of the blue molds on the oranges is more developed when the oranges are not bagged. In the case of bagged oranges inoculated with $P$. italicum, the respiration in the bag was reduced and the spread was limited.

The visible spores and damage on the peel of differently treated oranges after 14 days of storage are presented in Figure 2.

As mentioned previously, bagging has slowed down the growth of $P$. italicum on the stored oranges, which can be seen in Figure 2. $\mathrm{O}_{2}$ and $\mathrm{CO}_{2}$ content. Modified Atmosphere Packaging (MAP) extends shelf life and preserves the food quality without additives or preservatives. Shelf life of fresh foods is significantly extended, while spoilage and waste are reduced. MAP works on the concept of reducing the level of oxygen $\left(\mathrm{O}_{2}\right)$ inside the bag and at the same time increases concentration of carbon dioxide $\left(\mathrm{CO}_{2}\right)$.

The results showed that $\mathrm{O}_{2}$ content is statistically significantly reduced in all bagged samples (Figure 3 ). The content of $\mathrm{O}_{2}$ in the bags with inoculated oranges was smaller in comparison to the control samples. Hence, the fungi use the $\mathrm{O}_{2}$ from the bags, and produce the $\mathrm{CO}_{2}$. Both fungi had equal influence on the reduction of the level of $\mathrm{O}_{2}$ in bag, although, the production of $\mathrm{CO}_{2}$ was statistically higher in the bags with orange inoculated with the $P$. italicum. This slowed down the growth of $P$. italicum spores in the bagged orange fruits.

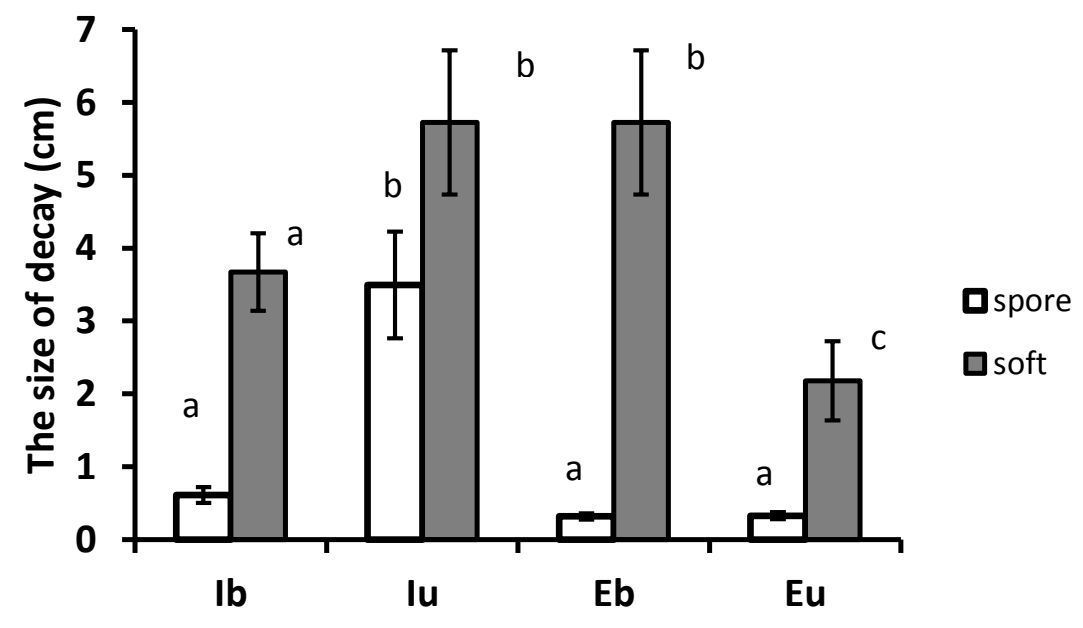

Figure 1. Colony size and lesion area $(\mathrm{cm})$ of orange fruit inoculated with Penicillium italicum with bag (Ib), without bag (lu) and $P$. expansum with bag (Eb), without bag (Eu) after 14 days of storage. The same latter on the figure denote a not significant difference according to Tukey's test at $p<0.05$ 


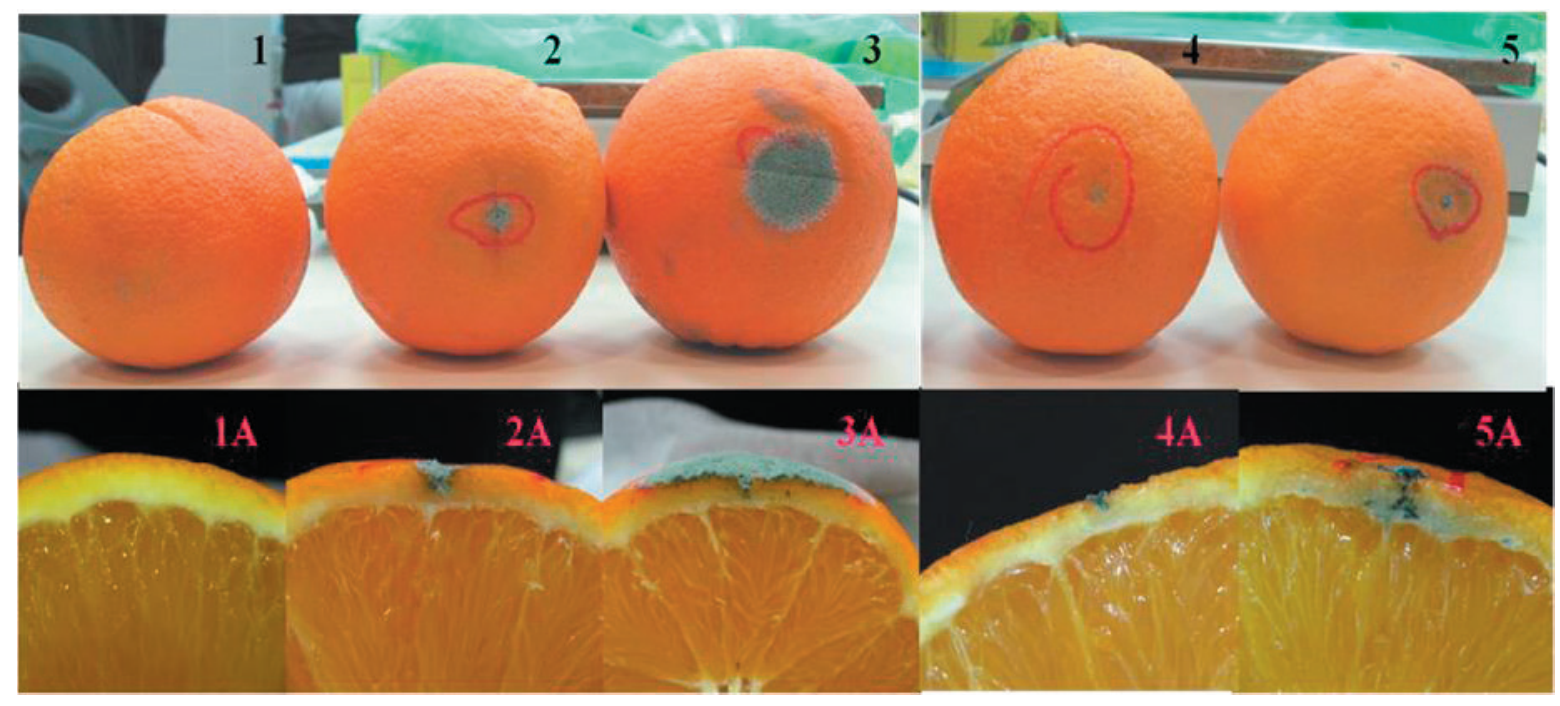

Figure 2. Visible spores around inoculation site and damage at the peel of an orange. Control (1. 1A) $P$. italicum in bag (2. 2A) and unbagged (3.3A). P. expansum in bag (4. 4A) and unbagged (5.5A) after 14 days of storage

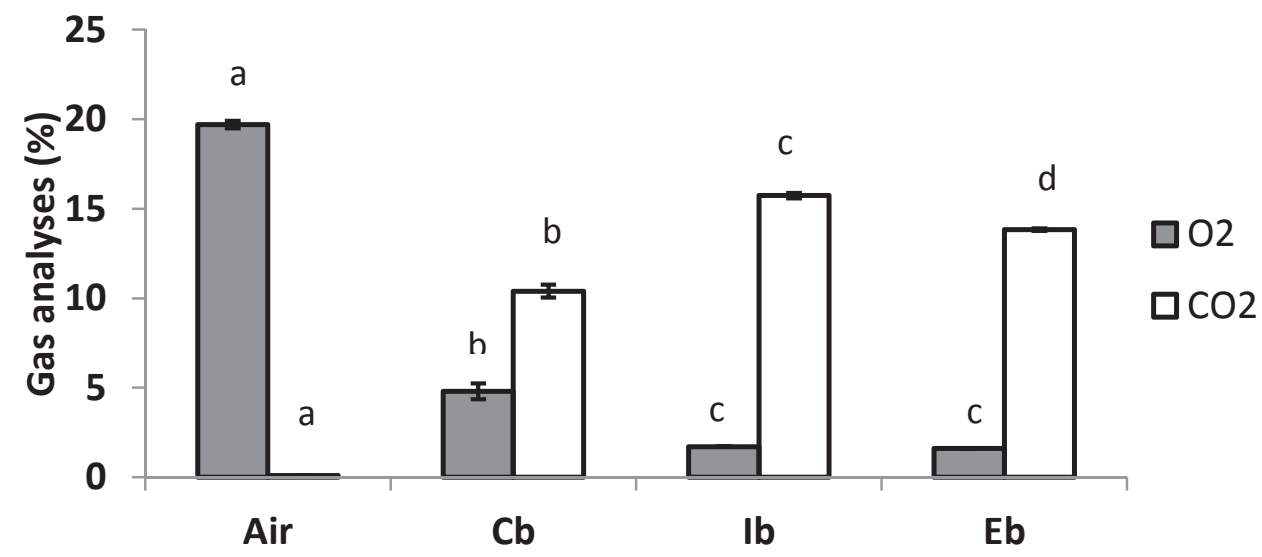

Figure 3. $\mathrm{O}_{2}$ and $\mathrm{CO}_{2}$ content in bags with orange fruits inoculated with Penicillium italicum $(\mathrm{Ib})$ and $P$. expansum $(\mathrm{Eb})$ after 14 days of storage ( $\mathrm{Cb}$-control). The same latter on the figure denote a not significant difference according to Tukey's test at $p<0.05$

\section{DIscussion}

In this work, infection capacity of $P$. italicum and $P$. expansum in orange during storage was studied. $P$. expansum showed the development of rot in orange peel after 14 days of inoculation in bag but the growth was limited in the inoculation area. Vilanova et al. (2012a) reported that $P$. expansum could infect oranges at commercial maturity. At concentration $10^{6} \mathrm{co}-$ nidia $\mathrm{mL}^{-1}$ infection could only develop in over-matured oranges, while the concentration $10^{5}$ or $10^{4}$ conidia $\mathrm{mL}^{-1} P$. ex- pansum was not able to induce decay. $P$. digitatum, which is the gray mould rot of orange, was able to infect apple at very late stages of apple fruit maturity and disease symptoms limited to the initial infection site (Vilanova et al., 2012b). The weight loss and firmness of fruit that were infected by $P$. expansum have the same rate of decrease as control samples. Spore and water soaked area were found in oranges inoculated with $P$. italicum and were wider when kept without bagging. The orange which had more area covered by spores losses more firmness. Bag may 
control the fungus $P$. italicum by limited oxygen. Penicillium spp. is aerobic and can grow under low oxygen conditions if nutrient sources are provided (Kinsey et al., 2003). Fungi consume oxygen for respiration and release carbon dioxide so that oxygen level in bag with $P$. italicum and $P$. expansum was lower than control and also the percentage of carbon dioxide in orange inoculated by $P$. italicum and $P$. expansum was increased.

Economic aspect. $P$. italicum spores infection in oranges causes decay which leads to the losses. The most important are the financial losses to the farmers and traders caused by this pathogen. In order to reduce financial losses and export sufficient amounts of orange to the foreign market, the oranges have been produced on larger areas but this has led to overuse of land, water and labor. The production of oranges on larger areas will also lead to loss of sustainability due to overuse of scarce production resources i.e. land, water, fertilizers, chemicals and labor. This problem leads to food shortage as farmers switch to other crops $\backslash$ fruits with less postharvest losses and discourage the youth from joining farming as an income generating enterprise.

\section{CONCLUSIONS}

Bagging of oranges after harvest reduces the growth of $P$. italicum. This mold causes decay which leads to significant postharvest losses in oranges. Its main entry point is bruising injury or mechanical damages, hence good care should be taken during harvesting, sorting and packing of oranges. Gas levels inside the bag showed the reduction of oxygen and a higher concentration of carbon dioxide, which helped to slow down the growth of $P$. italicum, and at the same time, maintained the freshness of the oranges. On the other hand, $P$. expansum caused no damage/ decay to the oranges.

\section{ACKNOWLEDGEMENT}

We are grateful to the Israel Agency for International Development Cooperation Ministry of Foreign Affairs (MASHAV), Agricultural Research Organization (ARO) and the Ministry of Agriculture and Rural Development Centre for Agricultural Development Cooperation (CINADCO) for organizing this International R\&D Course on Postharvest Physiology, Pathology and Handling of Fresh Commodities, Prof. Eli Fallik, Mr. Meir Baze let and team who have not hidden anything in Postharvest management from us.

\section{REFERENCES}

1. Abdel Wahab, S.M., Rashid, A.S. (2012). Safe postharvest treatments for controlling Penicillium molds and its impact maintaining naval orange fruit quality. American-Eurasian Journal of Agricultural and Environmental Science, 12 (7), 973-982.

2. Adaskaveg, J.E., Forster, H. (2015). Resistance in postharvest pathogens of citrus in the United States. In Fungicide Resistance in Plant Pathogens: Principals and a Guide to Practical Management. Eds. H. Ishii, D.W. Hollomon. Springer, Japan, pp. 449- 466.

3. AOAC (1990). Official Methods of Analysis of AOAC International, 15th Ed., AOAC International, Washington DC., USA, Official Method 950.15.

4. Barkai-Golan, R., Plaster, N. (2008). Mouldy fruits and vegetables as a source of mycotoxins: part 1. World Mycotoxin Journal, 1 (2), 14-159.

5. Ben-Yephet, Y., Shtienberg, D. (1997). Effects of the host, the pathogen, the environment and their interactions, on Fusarium wilt in carnation. Phytoparasitica, 25 (3), 207-216.

6. Berger, S., Sinha, A. K., Roitsch, T. (2007). Plant physiology meets phytopathology: plant primary metabolism and plant-pathogen interactions. Journal of Experimental Botany, 58, 4019-4026.

7. FAOstat. (2016) Food and Agricultural Organization of the United Nation. (http://www.fao.org/faostat/en/\#home).

8. Filtenborg, O., Frisvad, J.C., Traen, U. (1996). Moulds in food spoilage. International Journal of Food Microbiology, 33, 85-102.

9. Droby, S., Eick, A., Macarisin, D., Cohen, L., Rafael G., Stange, R., McColum, G., Dubai, N., Nasser, A., Wisniewski, M., Shapira, R. (2008). Role of citrus volatiles in host recognition. Germination and growth of Penicillium digitatum and Penicillium italicum. Postharvest Biology and Technology, 49 (3), 386-396.

10. Embaby, E.S.M., Hazaa, M., Hagag, L.F., Ibrahim, T.E.S., Ab.d el-Azem, F.S. (2013). Decay of some citrus fruit quality caused by fungi and their control: III- control blue and green mould decay by using some alternative fungicides. Journal of Applied Sciences Research, 9 (8), 5086-5096.

11. Kinsey, G., Paterson R., Kelly, J. (2003). Filamentous fungi in water systems. In Hand- 
book of Water and Wastewater Microbiology. Eds. D. Mara, N.J. Horan, Academic Press, London, UK, pp. 77-98.

12. Rosenberger, D.A. (1990). Blue mold. In $A$ Compendium of Apple and Pear Diseases. Eds. A.L. Jones, H.S. Aldwinckle, American Phytopathological Society, St. Paul, MN, pp. 54-55.

13. Snowdon, A.L. (1990). Post-Harvest Diseases and Disorders of Fruits and Vegetables, Vol 1, General Introduction \& Fruits, Manson Publishing, London, UK.

14. Stange, R.R., Midland, S.L., Sims, J.J., McCollum, T.G. (2002). Differential effects of citrus peel extracts on growth of Pencillium digitatum, $P$. itallicum, and $P$. expansum. Physiological and Molecular Plant Pathology, 61 (5), 303-311.

15. Staskawicz, B.J. (2001). Genetics of plantpathogen interactions specifying plant disease resistance. Plant Physiology, 125 (1), 73-76.
16. Statistica (Data Analysis Software System) (2013). v. 12. StatSoft. Inc., Tulsa, OK.

17. Vilanova, L., Viñas, I., Torres, R., Usall, J., Jauset, A. M., Teixidó, N. (2012 a). Infection capacities in the orange-pathogen relationship: compatible (Pencillium digitatum) and incomepatible (Penicillium expansum) interactions. Postharvest Biology and Technology, 29, 56-66.

18. Vilanova, L., Teixidó, N., Torres, R., Usall, J., Viñas, I. (2012 b). The infection capacity of Penicillium expansum and Pencillium digitatum on apples and histochemical analysis of host response. International Journal of Food Microbiology, 157 (3), 360-367.

19. Vilanova, L., Torres, R., Viñas, I., GonzálezCandeles, L., Usall, J., Fiori, S., Solsona, C., Teixidó, N. (2013). Wound response in orange as a resistance mechanism against Penicillium digitatum (pathogen) and $P$. expansum (nonhost pathogen). Postharvest Biology and Technology, 78, 113-122.

\title{
СПОСОБНОСТ ПАТОГЕНА Penicillium italicum И Р. expansum ДА ИНФИЦИРАЈУ ПОМОРАНЏЕ ТОКОМ СЛАДИШТЕЊА
}

\author{
Соња П. Вељовић ${ }^{* 1}$, Krissana Boonsiri ${ }^{2}$, Michael K. Maina ${ }^{3}$, Emmanuel M. Semavor ${ }^{4}$, Surajit Mitra ${ }^{5}$ \\ ${ }^{1}$ Економски институт, Краља Милана 16, 11000 Београд, Србија \\ ${ }^{2}$ Nakhonsawan Факултет пољопривреде и технологије, Тајланд \\ ${ }^{3}$ Кенијски извозници хортикултуре, Кенија \\ ${ }^{4}$ Волта Интегрисан Агрикултурни Развој, доо, Гана \\ ${ }^{5}$ Bidhan Chandra Krishi Viswavidyalaya Пољопривредни факултет, Департман за послежетвене \\ технологије, Моханпур-741252, Надија, Западни Бенгал, Индија
}

Сажетак: Penicillium italicum и P. expansum су најважнији патогени проузроковачи труљења различитих врста воћа и поврћа. У овој студији, поморанџе су инокулисане са ове две врсте плесни, а затим скадиштене 14 дана без врећа или упаковане у врећама, у хладној соби током 11 дана и 3 дана на собној температури, да би одредили утицај паковања и могућност инфекције поморанџи овим гљивама током сладиштења. Паковање није имало утицаја на садржај растворљиве суве материје (РСM) и чврстину. Састав гаса у врећама показује низак садржај кисеоника и високу концентрацију угљен диоксида након 14 дана складиштења. Паковање воћа у вреће смањило је труљење поморанџи изазвано гљивом $P$. italicum и губитак тежине, и очувало чврстину, РСМ и киселост у поређењу са контролним узорком воћа. Студија нам сугерише да паковање у вреће може бити успешно решење за контролисање труљења, очување квалитета воћа и продужење рока трајања поморанџи.

Кључне речи: поморанца, инокулација, паковање, инфекциони капацитет, квалитет воћа

Received: 11 January 2017

Accepted: 30 March 2017 